\title{
9 English Summary
}

In the spring of the year $622 \mathrm{CE}$, the emperor Heraclius (610 - 641), after having celebrated Easter in Constantinople, left the capital and crossed over to Anatolia; his aim was to prepare the Roman troops for a counter offensive against the Persians who had occupied the provinces of Syria, Mesopotamia, Palestine and Egypt. During the following years, Heraclius spent more time on the battlefield than in his imperial palace, at times advancing far into the Persian heartlands. In 628 his bold strategy paid off: unable to respond to the military pressure exerted by the Romans, the Sasanian King of Kings Chosroes II was overthrown and replaced by his son Kavadh Seiroe. The new ruler immediately proposed a truce, promising to vacate the occupied Roman territories. After years in the theatre of war, Heraclius returned to Constantinople in triumph.

Recent research has revealed the early seventh century to have been an exceptionally dynamic period, during which the Mediterranean and the Near East underwent a fundamental transformation. After the ephemeral Persian occupation, the Roman eastern provinces were granted only a few years of peace; from the early 630s onwards, Syria and Mesopotamia were confronted with the onsets of the Arab expansion. Weakened by decades of constant warfare, the Roman defence was not equipped to halt the new aggression. In 636, the Roman army suffered a crushing defeat by the Arab troops at the banks of the river Yarmouk; Heraclius' troops had no choice but to withdraw behind the natural border of the Taurus mountains. In the following years, the eastern provinces as well as Egypt and Africa fell to the new enemy; Heraclius' previous successes were obliterated: by the middle of the century, the Roman Empire was left with nothing but a core territory in Anatolia and Thrace as well as enclaves in Greece and Italy.

Against the backdrop of these large-scale processes, this book focuses on the development of the Eastern Roman monarchy in the early seventh century and discusses the opportunities and constraints of imperial rule. In this context, the fact that Heraclius personally acted as supreme commander against the Persians is of utmost importance. During the fifth and sixth centuries, the political system of the Eastern Roman Empire was characterized by a close physical and ideological bond between the emperor and Constantinople. Instead of travelling the provinces and leading the armies as their predecessors had done, the Eastern Roman monarchs virtually ceased to leave the new capital. In research, this specific configuration is often seen as a major reason for why the Eastern Empire survived the tumultuous period of Late Antiquity, whereas its western counterpart eventually succumbed to the pressure of mainly non-Roman military elites. After more than two hundred years of sedentary monarchy, Heraclius was the first emperor to leave Constantinople for an extended period of time in order to personally lead the Roman troops into battle. This book asks for the reasons for this shift of paradigm, it looks at the ways in which contemporaries coped with the sudden change in imperial behaviour and addresses the con- 
sequences of Heraclius' policies for the further development of the Eastern Roman monarchy. My aim is to not only recount Heraclius' reign but to highlight the structural mechanisms and causal foundations of political decision making as well as the impact of political communication.

The analysis centres around the relationship between the emperor, the capital and the military sector. As has been frequently emphasized in research, the sedentary type of monarchy of the fifth and sixth centuries effected a rise in the importance of the Constantinopolitan environment: the metropolitan people and elites played a major role in the process of negotiating imperial rule; their acceptance and support was paramount for the stability of an emperor's position. In turn, it has been argued that the military, which up until the late fourth century had made and unmade emperors, was gradually marginalized, losing its relevance for political processes once the emperors stayed in Constantinople. In contrast to this assessment, a revision of the relationship between the sedentary monarchs and the military sector during the fifth and sixth centuries, conducted in chapter 2, argues that certain groups within the military continued to make their influence felt. Whereas the mass of the soldiers did not pose a genuine threat as long as the emperors catered to their needs, high military officeholders - the magistri militum who by default rose to the rank of illustris and thus became members of the senate - had means at their disposal to transfer their prestige to the capital, put pressure on the emperor and influence political processes up to imperial succession. The same applies to the imperial guards, the scholae and excubitores, and especially to their commanders, whose control over the imperial palace was a major asset. The sedentary emperors, in turn, developed strategies to emancipate themselves from the military and curb the threat that was posed by high officeholders: within Constantinople, the emperors could draw on new forms of communication and representation structured by an increasing sacralization of the imperial office on the one hand and triumphalism on the other hand. As eternal victors, the sedentary and non-warring emperors succeeded in appropriating for themselves the triumphs won by their generals. Chapter 2 ends with a closer look at the reign of the emperor Maurice (581-602) who struggled to establish new ways of interacting with the military. His often insensitive measures, however, did not show the desired effect but sparked a backlash from both the metropolitan environment and the military, eventually contributing to his overthrow.

Chapter 3 traces a gradual shift in the relationship between emperor, the capital and the military sector in the early seventh century, which is closely related to a chain of events that unfolded in the fall of 602. After Maurice had ordered the Balkan army to winter beyond the Danube, the soldiers rebelled, chased away the magister militum Petrus, Maurice's brother, and acclaimed the centurion Phocas as their leader instead. As the army drew closer to Constantinople to enforce their claims, tension within the city walls also erupted. Given that the people had turned against him and parts of the city centre had been set ablaze, Maurice saw no other option but to flee the city at night and cross over to the Asian side of the Marmara See. In this power vacuum the green circus faction stepped forward and greeted Phocas as the new em- 
peror. Several days later, Maurice was seized and killed together with his family. In this book, the events of 602 are read as a contingent chain reaction. When the army first revolted against the imperial order, it had neither been planned nor foreseeable that Maurice would be overthrown and succeeded by Phocas. The result of this chain of events - the coronation of an external candidate -, however, broadened the space for manoeuvre: it had become clear that, as opposed to the centuries prior, military pressure could once again directly affect the metropolitan environment up to imperial succession. Only a few years later, Heraclius, the exarch of Carthage, made use of this option and rose up against Phocas. Numismatic evidence shows that, in this case, it was the aim from the start to overthrow the emperor and install Heraclius' son of the same name in his stead. Having secured Egypt and parts of the Levant by military force, a fleet led by Heraclius Junior sailed towards Constantinople. When faced with the contender anchoring in the harbours south of the city in October 610, the metropolitan people and elites deserted Phocas and acclaimed Heraclius emperor instead. The analysis of the coronation rituals of Phocas and Heraclius shows the unbroken impact of the metropolitan environment: involving the major Constantinopolitan interest groups, a cautiously staged ritual succeeded in transferring two external candidates into the city as new emperors and overcoming a period of internal strife and disintegration. Before Heraclius was crowned emperor in the Hagia Sophia, his predecessor Phocas, who had been frantically acclaimed by the metropolitan people eight years prior, was publicly humiliated and executed: having failed to establish functioning forms of communication and to sustain the necessary support as emperor, Phocas suffered the symbolic treatment of a failed usurper. As the last subchapter shows, the vilification of Phocas as tyrant formed a core aspect of Heraclius' self-representation and became so deeply ingrained in collective memory that it shapes historiography until today.

Chapter 4 looks at the remilitarization of the imperial office under Heraclius. After his coronation, Heraclius' main challenge was to prevent the scenario that had brought himself to power from happening again: he had to forestall another usurpation from the military sector. Whereas his predecessor Phocas had remained in Constantinople despite his military background and the reignited war with the Persians, Heraclius broke new ground. As Sasanian troops raided Syria and Anatolia, he left Constantinople in 613 to face the enemy in battle; the Roman army under his lead, however, suffered a crushing defeat. This situation showcases the risk Heraclius took by personally leading the troops: whereas his sedentary predecessors had been able to immunize themselves from the consequences of military defeat, the warring emperor could be held accountable; his prestige and standing could potentially suffer a severe blow. After this first unsuccessful advance, Heraclius withdrew to Constantinople. Only after the Persians had occupied vast parts of the Roman Empire, he seems to have seen no other choice but to prepare for another personal counter offensive: in 622 the emperor led a campaign in Asia Minor; in 624 he left the capital for several years to fight the Persians on their own territory. By leading the Roman army in person, Heraclius reacted to a Persian aggression that was far 
more severe than what the empire had experienced in the previous centuries; however, he simultaneously tried to curb an internal threat from the military sector: acting as supreme commander, Heraclius aimed at strengthening imperial authority over the military so as to prevent military officeholders from becoming too powerful and having designs on another usurpation. Heraclius' policies, however, were not only directed at the military; he also showed innovative approaches in the realm of family politics. In 613, shortly before he left for his first campaign against the Persians, he crowned his baby son Heraclius Constantine Augustus and systematically propagated this step on the obverses of gold, silver and copper coins. Despite Heraclius' temporary absence, there was always an Augustus present in the capital, who, despite his young age, could substitute for his father as the ceremonial centre of the imperial palace. By elevating his son as imperial colleague, Heraclius not only strengthened his family but made a clear statement as to imperial succession. In this context, a much-debated aspect of Heraclius' reign reveals its substance: after the early death of his first wife Eudocia, he married his niece Martina - a connection that defied Roman law and sparked controversy. In the fifth and sixth centuries, military officeholders had frequently tried to assert their influence and even position themselves for imperial succession by marrying into the imperial family. With his endogamous family policy and by systematically promoting family members like his cousin Nicetas to the highest positions, Heraclius tried to pre-empt potential contenders from entering into the highest echelons of power.

Chapter 5 turns towards the contemporary discourse. As the coups of 602 and 610 had shown, an emperor had to secure the support of the metropolitan groups in order to stay in power. By leaving the capital, however, Heraclius broke with established patterns of imperial behaviour; as the sources show, his attempt to act as supreme commander was heavily debated in Constantinople and at times faced a serious backlash. To not jeopardize his authority, Heraclius' transgression had to be framed with an acceptable narrative. In the panegyric poems of George of Pisidia, of which many can be read as a direct comment on current events, we can trace a process of negotiating the imperial position throughout Heraclius' reign. When presenting his elaborate verses in the imperial palace, George, himself a cleric in the staff of the patriarch Sergius, formed a communicative link between the emperor, the metropolitan elite and the church. In these poems, the war against the Persians is put into an explicitly religious framework as a conflict between Christians and Zoroastrian idolaters. Against this backdrop, Heraclius' engagement as supreme commander also gained religious implications. Leaving behind the aloof figurations of earlier emperors, George presented the warring Heraclius as a supreme commander fighting like one of his soldiers, struggling and sweating on the battlefield. The images evoked by George strengthened Heraclius' authority over the military sector; simultaneously, however, his verses drew on a religious frame of reference: by using vocabulary reminiscent of hagiography, the poet modelled the emperor's generalship according to the ascetic practice of Holy Men. The impact of communication becomes even more clear when, in 626, Constantinople had to face a double siege by the Avars 
and Persians while Heraclius remained with his army in eastern Anatolia. As the emperor, due to his absence, was unable to fulfil his traditional role as protector of the metropolitan people, George established two alternative figures of identification, the patriarch Sergius and the Virgin Mary, who filled the vacuum left by Heraclius without challenging his authority, thus leaving no room for potential political contenders. Marian devotion, which had already played a crucial role in Constantinople in the sixth century, reached a preliminary peak. In retrospect, the precarious situation was not only overcome but turned into a moment of civic pride which strengthened political and religious hierarchies and contributed to the city's resilience. After the victory over the Persians and his triumphal return to the capital, the sweating emperor, in George's laudatory words, was turned into a transcendental saviour figure, whereas Heraclius himself acted as a humble and God-fearing ruler. In Constantinople the Roman triumph was seen as the key to a new and better future; meanwhile, in the Eastern provinces which had suffered from several reversals of fortune during the past decades, recent developments in general and Heraclius' engagement in particular were interpreted in explicitly apocalyptic terms.

Chapter 6 turns the focus towards the last one and a half decades of Heraclius' reign and starts by assessing how Heraclius was practically reintegrated into Constantinople after years of absence. On the back of his spectacular victory, Heraclius could celebrate a triumphal return that connected liturgical elements with traditional forms of Roman victory festivities like hippodrome games. However, instead of remaining in the capital, Heraclius left for the eastern provinces again, intent on reintegrating the areas he had just regained for the Roman Empire. Having formed an alliance with the Persian general Shahrbaraz, Heraclius demanded the return of the relic of the True Cross which the Persians had taken from the Anastasis Church in Jerusalem in 614. In 630, Heraclius celebrated another triumph in a setting that was much less structured by norms and expectations than the imperial capital: he entered Jerusalem and returned the True Cross to its accustomed place, becoming the first Christian emperor to ever visit the holy city. Unsurprisingly, the Restitutio Crucis has received much scholarly attention: what remains undisputed is that contemporaries perceived it as an event of cosmic significance and that the ceremony seems to have played with parallels to Jesus' entry into Jerusalem. In my analysis of Heraclius' entry, however, I argue against the common notion that the emperor aimed at presenting himself as a new David and that he intended to put his visit to Jerusalem into an eschatological context. The evidence for this claim is too scarce, fragmented or removed from the actual event in space and time. In Constantinople, as another poem of George of Pisidia makes clear, Heraclius was not portrayed in relation to David but in explicit analogy to the emperor Constantine. After his Restitutio Crucis, Heraclius devoted himself to solving the religious strife between the different Christian denominations of the Near East. He personally met with representatives of the miaphysite Syrian and Armenian Churches, as well as with Nestorian Christians, to promote a new formula (monoenergism or later monotheletism) that was meant to appeal to all denominations. In the contemporary discourse of the cap- 
ital, however, these politics of reconciliation found no expression; instead, Heraclius was portrayed as a divinely inspired fighter for orthodoxy, crushing the Persians and the heresies alike. Yet, like so many of his predecessors, Heraclius did not succeed in his efforts to unify Christianity. While opposition against monoenergism rose from both the miaphysite and the chalcedonian side, Palestine and Syria had to face the first Arab attacks. When the Roman army suffered a crushing defeat at the banks of the river Yarmouk in 636, Heraclius returned to Constantinople. The last subchapter explores the consequences of this military disaster. After no one had dared to directly challenge Heraclius over several decades, a conspiracy against him, led by members of his own family, was hatched in Constantinople. As the conspiracy was revealed and those responsible punished, Heraclius felt the need to reclaim his position in the capital. Even though there was nothing to celebrate, he ordered a bridge of boats to be constructed over the Bosporus; having crossed the waters on horseback, he entered Constantinople. The emperor's spectacular and triumphal statement, however, was not remembered as such; as the Romans were unable to halt the Arab advance and the religious policy failed, the bridge of boats was ridiculed as a symbol of Heraclius' alleged fear of water.

In 641, Heraclius died a natural death. He had succeeded in securing his own position as emperor; his measures, however, quickly revealed substantial issues as chapter 7 shows. After the conspiracy in the wake of the battle of Yarmouk had challenged his authority, Heraclius had elevated a second son (Heraclonas, son of his second wife Martina), to the rank of Augustus. Given that there was no clear order of succession, a feud broke out between the two lines of the imperial family after Heraclius' death: his oldest son Heraclius Constantine, son of Eudocia and Augustus since 613 on the one side, and Martina and Heraclonas on the other fought for supremacy in Constantinople. In this unstable constellation, the group that Heraclius had been able to curb re-emerged as a major political factor: high military officeholders with the mass of soldiers behind them started putting pressure on Constantinople. After Heraclius Constantine's premature death, a rebellious army under the lead of the general Valentinus insisted on securing the position of Heraclius Constantine's infant son, who was crowned Augustus as Constans II in late 641. In what seems to be a military coup, Martina and Heraclonas were overthrown shortly afterwards. Valentinus, who by then had made his way into the palace, continuously tightened his grip on Constans II and tried to position himself and his family for imperial succession. By instituting a veritable military regime, however, he went one step too far: the metropolitan people, supported by the patriarch, rose against Valentinus and confirmed Constans as emperor. The Heraclian dynasty proved remarkably persistent, reigning over five generations; imperial succession, however, was regularly accompanied by family strife and infighting. With his remilitarization of the imperial office, Heraclius had set a precedent; his successors left the capital to lead the armies in person. Constans' attempt, however, to establish a new residency in Syracuse, Sicily, was heavily contested and eventually cost the emperor's life; Constantinople remained the Empire's undisputed centre. In the course of the seventh century, how- 
ever, crisis phenomena increased: while the Arabs established their rule on formerly Roman territories, rebellions from the military became more and more frequent; Justinian II, the last representative of the Heraclian dynasty, had to face several usurpations by powerful generals until he was eventually executed in 711 and succeeded by Philippikos Bardanes.

Identifying the reign of Heraclius as a crucial period in the development of the Eastern Roman monarchy, this book contributes to the discussion of the transition between Antiquity and the Middle Ages in the Eastern Mediterranean. As to the opportunities and constraints of imperial rule, Heraclius, in his attempts to secure his position and curb the threats from the military sector, set new standards by which his successors had to abide. What remained, however, was the structural setting established during the fifth and sixth centuries in which the emperor had to secure Constantinople and gain the acceptance of the relevant groups in order to stay in power. In the early seventh century, Constantinople underwent a process of civic integration by strengthening a common frame of reference - a process that substantially contributed to the city's unbroken importance and its resilience in the face of the Arab expansion. This frame of reference in which also the emperors negotiated their position was, by now, a comprehensively Christian one and can be qualified as distinctively byzantine. The ways in which imperial warfare in general and the engagement of the emperor in particular had been communicated under Heraclius - as a religious war with an almost sacred leader - showed its full impact in the centuries to come. 